\title{
PAUL REVERE A DENTIST.**
}

\author{
By Henry Lovejoy Ambler, M.S., D. D.S., M. D., Cleveland, Ohio.
}

(Read before the Preparedness League of American Dentists, Cleveland Unit.)

It may not be generally known that Paul Revere, The Revolutionary Patriot, besides being a gold and silver smith, expert worker in bronze and other metals, also practiced dentistry in Boston. In the Dental Summary of October, 1909 , at page 769 , appears an article by the author on "Early Dentistry in America," which contains a history of Paul Re. vere as a Dentist. Among his many other accomplishments he practiced making artificial teeth and evidently learned this work from one John Baker, Surgeon Dentist. In the Boston Gazette for December 26th, 1768, there appears the following: "Whereas, so many persons are so unfortunate as to lose their fore teeth by accident, and other ways, to their great detriment, not only in looks, but speaking, both in public and private. This is to inform all such that they may have them replaced with artificial ones that look as well as the natural, and answer the end of speaking to all intents, by Paul

*Dr. H. C. Kenyon, of Cleveland, Ohio, remembering that Paul Revere was a dentist recognized the possibilities in the picture when it appeared in the Cleveland Plain Dealer with another inscription. The generous consent of the eminent cartoonist, Mr. J. H. Donahey was readily secured, and the necessary changes were made in the pic ture. It has been adopted by the Cleveland Unit as an emblem and plates were made to be used on all of their stationery. It has since been adopted by the Preparedness League of the National Dental Association as its emblem.-Editor.
Revere, goldsmith, near the head of Dr. Clarke's wharf, Boston. All persons who have had false teeth fixt by John Baker, surgeon dentist, and they have got loose (as they will in time) may have them

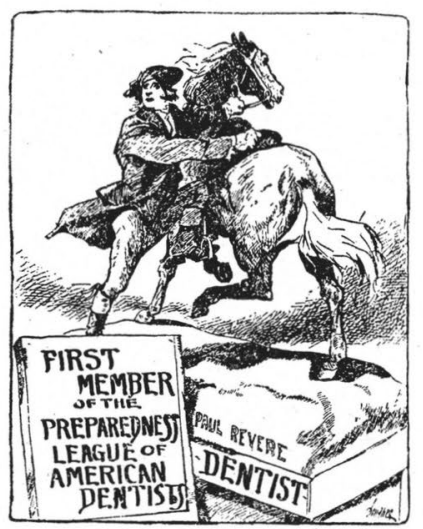

fastened by the above (who learnt the method of fixing them from Mr. John Baker)." "Revere lived on Fish street and carried on the business of goldsmith, silversmith, engraver, and dentist, so far, at least, as to make and set artificial teeth, then called a new invention. The Granary burying ground in Boston was established in 1660 , and here is intered the ardent patriot and ingenious mechanical artist, the messenger of the Midnight Ride, immortalized by Longfellow." 